\title{
Complex assessment of complications in operated patients with Fallot's tetrad at the hospital stage
}

\author{
Rakhima Mekenbayeva ${ }^{1}$, Anar Sarsembayeva ${ }^{1}$, Akkerbez Adilbek ${ }^{1}$, Dias Vakpayev ${ }^{1}$, Nigina Mekenbaeva ${ }^{2}$, \\ Arman Akseitov ${ }^{2}$
}

${ }^{1}$ Pediatric Cardiac Surgery Department, National Scientific Medical Center, Nur-Sultan city, Republic of Kazakhstan

${ }^{2}$ Astana Medical University, Nur-Sultan city, Republic of Kazakhstan

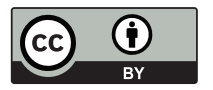

This work is licensed under a Creative Commons Attribution 4.0 International License

Received: 2019-04-30

Accepted: 2019-11-30

UDC: 616.1

J Clin Med Kaz 2019; 4(54):25-33

Corresponding Author: Rakhima Mekenbayeva, MD, PhD, Pediatric Cardiac Surgery Department, National Scientific Medical Center. Address: $7 \backslash 1$ Mailin Street, 010000 Nur-Sultan city, Republic of Kazakhstan. Tel.: +7 (705) 485-75-81

E-mail: mrt.14@mail.ru

\section{Abstract}

Fallo's tetrad - one of the most often found congenital heart disease. The relevance of a problem of complications after cardiac operations at the Fallo's tetrad remains acute for today. The analysis of results of expeditious treatment and complications will allow to solve problems of timely diagnostics, treatment and prevention of the reasons of an unsatisfactory clinical condition of patients at all stages of postoperative maintaining.

Objective: Studying the structure of postoperative complications, determination of the causes of postoperative complications at a hospital stage at patients after a definitive and palliative repair of Fallo's tetrad definition of diagnostic and medical tactics in the postoperative period.

Material and methods: The studied patients with Fallo's tetrad (126 children aged from 2 days till 9 years, from them boys - 64, girls - 62) were distributed on 2 main groups: after the definitive repair of defect (DRD) and after the palliative correction of defect (PCD). The complex assessment of postoperative complications at patients with TF was carried out with use of clinical-laboratory research methods.

Results: Complications at a hospital stage arose in $38(45.2 \%)$ cases from 84 $(100 \%)$ patients after a definitive repair and in $17(50 \%)$ cases from $34(100 \%)$ - after palliative correction of Fallo's tetrad. The structure of complications after a definitive and palliative repair of defect is defined. The reasons and risk factors of development of postoperative complications after surgical correction of Fallo's tetrad are defined. Features of a clinical current of complications after a definitive and palliative repair of Fallo's tetrad are noted. Optimum tactics in treatment of postoperative complications at a hospital stage after a definitive and palliative repair of Fallo's tetrad is defined.

Key words: Fallo's tetrad, radical and palliative correction, post-operative complications

\section{ТЕТРАДА ФАЛЛО ДИАГНОЗЫ БОЙЫНША ОТА ЖАСАЛҒАН НАУҚАСТАРДАҒЫ АСҚЫНУЛАРДЫ КЕШЕНДІ}

БАҒАЛАУ

Мекенбаева Р.Т. ${ }^{1}$, Сәрсембаева А.А. ${ }^{1}$, Әділбекова А.Б. ${ }^{1}$, Вакпаев Д.О. ${ }^{1}$, Мекенбаева Н.Б. ${ }^{2}$, Аксеитов А.М. ${ }^{2}$

'Балалар кардиохирургия бөлімі, Ұлттық ғылыми медициналық орталық, Нұр-Сұлтан қаласы, Қазақстан Республикасы

${ }^{2}$ Астана медициналық университеті, Нұр-Сұлтан қаласы, Қазақстан Республикасы

\section{ТҰЖЫРЫМДАМА}

Фалло тетрадасы - жиі кездесетін туа біткен жүрек кемістігінің бірі. Фалло тетраданы емдеу мақсатымен жасалған кардиохирургиялық отадаң кейінгі асқынулардың мәселесінің өзектілігі қазіргі таңда өте маңызды болып саналады. Хирургиялық емдеу және асқынулардың нәтижелерің талдауы мерзімді диагностика, емдеу және отадаң кейінгі кезеңнің барлық кезеңдерінде пациенттердің қанағаттанарлықсыз клиникалық жағдайының себептерінің профилактика жолдарын шешуге мүмкіндік береді.

Мақсаты: Операциядан кейінгі асқынулардың құрылымын зерттеу, операциядан кейінгі кезеңде диагностикалық және терапиялық тактиканы анықтау, ТФ-да радикалды және паллиативтік түзетуден кейін науқастардың стационарлық кезеңінде операциядан кейінгі асқынулардың себептерін анықтау.

Материалдар мен әдістер: Фалло тетрадасымен зерттелген науқастар (2 күн 9 жасқа дейінгі 126 бала, оның ішінде ұлдар - 64, қыздар - 62) 2 негізгі топқа бөлінді: радикалды кемшіліктерді түзетуден кейін және паллиативтік кемшіліктерді түзеткеннен кейін. Фалло тетрадасы емделушілерде операциядан кейінгі асқынуларды кешенді бағалау клиникалық, аспаптық, зертханалық зерттеу әдістерін қолдана отырып жүргізілді.

Нәтижелері: Госпитальдік кезеңінде радикалды түзетуден кейін 84 (100\%) науқастың саңында 38 (45,2\%) науқастарда, ал Фалло тетрадасы паллиативтік түзетуден кейін 34 (100\%) науқастың саңында 17 (50\%) науқастарда асқынулар байқалды. Ақауларды радикалды 
және паллиативтік түзетуден кейінгі асқынулардың құрылымы анықталды. ТФ хирургиялық түзетуден кейін операциядан кейінгі асқынулардың даму себептері мен қауіп факторлары анықталды. Фалло тетрадасын радикалды және паллиативтік түзетуден кейінгі асқынулардың клиникалық ағымы ерекшеліктері анықталды. Фалло тетрадасын радикалды және паллиативтік түзетуден кейін стационар сатысында операциядан кейінгі асқынуларды емдеудегі оңтайлы тактика анықталды.

Негізгі сөздер: Фалло тетрадасы, радикалды және паллиативті кемшіліктерді түзету, отадан кейнгі асқынулар

\section{КОМПЛЕКСНАЯ ОЦЕНКА ОСЛОЖНЕНИЙ У ОПЕРИРОВАННЫХ ПАЦИЕНТОВ С ТЕТРАДОЙ ФАЛЛО НА ГОСПИТАЛЬНОМ ЭТАПЕ}

Мекенбаева Р.Т. ${ }^{1}$, Сарсембаева А.А. ${ }^{1}$, Әділбекова А.Б. ${ }^{1}$, Вакпаев Д.О. ${ }^{1}$, Мекенбаева Н.Б. ${ }^{2}$, Аксеитов А.М. $^{2}$

${ }^{1}$ Отделение детской кардиохирургии, Национальный научный медицинский центр, город Нур-Султан, Республика Казахстан

${ }^{2}$ Медицинский университет Астана, Нур-Султан, Республика Казахстан

\section{PEЗЮME}

Тетрада Фалло - один из наиболее часто встречающихся врожденных пороков сердца. Актуальность проблемы осложнений после кардиохирургических операций при тетраде Фалло на сегодня остается острой. Анализ результатов оперативного лечения и осложнений позволит решить задачи по своевременной диагностике, лечению и профилактике причин неудовлетворительного клинического состояния пациентов на всех этапах послеоперационного ведения.

Цель: Изучение структуры послеоперационных осложнений, определение причин возникновения послеоперационных осложнений на госпитальном этапе у пациентов после радикальной и паллиативной коррекции Тетрады Фалло, определение диагностической и лечебной тактики в послеоперационном периоде.

Материал и методы: Исследуемые пациенты с Тетрадой Фалло (126 детей в возрасте от 2 дней до 9 лет, из них мальчики - 64, девочки 62) были распределены на 2 основные группы: после радикальной коррекции порока и после паллиативной коррекции порока. Комплексная оценка послеоперационных осложнений у пациентов с Тетрадой Фалло была проведена с использованием клинико-инструментальных, лабораторных методов исследования.

Результаты: Осложнения на госпитальном этапе возникли в 38 (45,2\%) случаев из 84 (100\%) пациентов после радикальной коррекции и в 17 (50\%) случаях из 34 (100\%) - после паллиативной коррекции Тетрады Фалло. Определена структура осложнений после радикальной и паллиативной коррекции порока. Определены причины и фракторы риска развития послеоперационных осложнений после хирургической коррекции Тетрады Фалло. Отмечены особенности клинического течения осложнений после радикальной и паллиативной коррекции Тетрады Фалло. Определена оптимальная тактика в лечении послеоперационных осложнений на госпитальном этапе после радикальной и паллиативной коррекции Тетрады Фалло.

Ключевые слова: тетрада Фалло, радикальная и паллиативная коррекция, послеоперационные осложнения

\section{Introduction}

The urgency of the problem of complications after cardiac surgery in the tetralogy of Fallot (TF) is still sharp. The need for a systematic approach in assessing the results of surgical treatment of complex congenital heart diseases (CHD) is quite justified and logical. The health and quality of life of patients after cardiac surgery in TF depend on the adequacy of the surgical correction performed, on the course of the early postoperative period and the development of complications. Analysis of the results of surgical treatment and complications will solve the problem of timely diagnosis, treatment and prevention of causes of poor clinical condition of patients at all stages of postoperative management.

Tetralogy of Fallot is one of the most common CHD [1,2]. Currently, considerable experience of radical and palliative correction of $\mathrm{TF}$ has been accumulated in many cardiac surgery clinics of the world $[3,4,5,6,7,11]$. However, despite the perfection of surgical technique for correction of $\mathrm{TF}$, anesthetic aid and intensive care, it is impossible to prevent the development of complications in the postoperative period. The probability of complications at the postoperative stage is very high, which increases the responsibility of the cardiologist who determines the tactics of the operated patient $[8,9,10,11]$.

One of the expected and natural complications is chronic heart failure (CHF), which initially occurs at the preoperative stage. However, the following factors are important for the diagnosis and therapy of CHF: residual ventricular septal discharge, presence of systolic pressure gradient $(\mathrm{PG})$ in the right ventricular outflow tract (RVOT) and/or on the pulmonary artery valve (PAV), tricuspid valve insufficiency, myocardial dysfunction, rhythm and conduction disorders $[10,12,16]$. Complicating the clinical course of complications in the postoperative period are pleurisy and/or pericarditis, which develop due to heart failure and affect the function of the heart and lungs. Thus, a vicious circle is closed, leading to the prolongation of the stay of operated patients in the clinic $[13,14,15,18]$.
Purulent-septic complications after TF correction are an actual problem of nursing operated patients at the hospital stage. The causes of septic complications are initial immunodeficiency and acute inflammatory response to operational stress [13,17].

Given the above, it seems relevant to analyze complications in patients after surgical correction of TF to determine the possible causes of their occurrence for the purpose of early diagnosis, treatment and prevention at the hospital stage. Detailed examination of patients will optimize treatment tactics with the exception of the risks of repeated operations.

The aim of the study was to study the structure of postoperative complications, determine the causes of postoperative complications at the hospital stage in patients after radical and palliative correction of TF, and determine the diagnostic and therapeutic tactics in the postoperative period.

\section{Objectives}

1. To study the structure of postoperative complications arising in patients at the hospital stage after radical and palliative correction of TF.

2. To determine the causes and risk factors for the development of postoperative complications at the hospital stage in patients after radical and palliative correction of TF.

3. To identify and compare the features of the clinical course of complications after radical and palliative correction of TF.

4. To evaluate the management tactics of patients in the treatment of postoperative complications at the hospital stage after radical and palliative correction of TF.

\section{Material and methods}

The study patients with TF (126 children aged 2 days to 9 years, including boys-64, girls-62) were divided into 2 main groups:

Group I - 92 (73\%) patients with TF after radical correction of the defect (RCD). Patients of this group were divided into subgroups depending on age, on the stages of surgical correction (stage 1 and stage 2), on the method of surgical correction (valve- 
preserving and transannular operations). These subgroups also include deceased children, taking into account all of the above criteria.

Group II - 34 (27\%) patients with $\mathrm{TF}$ after radical correction of the defect (PCD) in the form of SPA (systemicpulmonary anastomoses). Children of this group are divided into subgroups depending on age. These subgroups also include deceased children.

Complications at the hospital stage occurred in 38 (45.2\%) cases out of $84(100 \%)$ patients after radical correction and in 17 $(50 \%)$ cases out of $34(100 \%)$ - after palliative correction of TF. In addition, concomitant complications at the hospital stage were observed in $19(22.6 \%)$ in the group after RDC and concomitant diseases aggravating the initial state - in $27(32 \%)$ patients out of $84(100 \%)$. Comparison of clinical and instrumental indicators was carried out between patients with postoperative (n\o) complications and patients without $n \backslash$ complications by groups.

The patients were operated in the children's cardiac surgery clinic of the NSMC in the conditions of artificial blood circulation (EC) according to the generally accepted method. Examination of patients was carried out using clinical, laboratory and instrumental methods (echocardiography, radiography, catheterization of the heart cavities, if necessary, computer tomography of the heart and blood vessels) before and after surgery in dynamics.

Primary radical correction of TF (stage 1) was performed in $61(72.6 \%)$ children from 84 , secondary RCD of TF after the imposition of SPA (stage 2) was performed in $23(27.4 \%)$ children from 84 . Systemic-pulmonary anastomoses (SPA) were performed in $34(100 \%)$ cases.

Clinical evaluation of heart failure in patients with TF was performed according to the functional classification of the New York Heart Association (NYHA).

Echocardiography was carried out in all patients on day 2, 4-5 days after surgery, if necessary in dynamics until discharge, in order to assess the status of intracardiac structures, systolic myocardial function and intracardiac hemodynamics, on the Philips Affiniti 70 apparatus. Sensors 12S, 6S, 4S were used.
Echocardiography was performed in 2D, M-modes, CW, PW (Doppler study). Standard and modified parasternal, apical, and subcostal approaches were used. The resulting image was recorded on a CD-ROM followed by frame-by-frame analysis of the recording. Hemodynamically significant criteria were residual pressure gradient (PG) at RVOT and/or PAV more than $30 \mathrm{~mm} \mathrm{Hg}$. For example, insufficiency of the tricuspid valve (TV) and the valve LA more than 1 degree, the diameter of the residual defect at the level of interventricular septum (IVS) more than $5 \mathrm{~mm}$.

Laboratory methods were used to assess peripheral blood parameters, with the determination of leukoformula and inflammatory markers (blood for presepsin, procalcitonin), immunograms. The data of microbiological studies (blood for sterility, culture of wound discharge for sterility, with determination of sensitivity to antibiotics) were analyzed in a group of patients with purulent-septic complications.

Statistical processing of the material was carried out using the Biostat program. To compare percentages in different groups, the criterion X2 was used to analyze data from feature conjugacy tables. The differences between the indicators were considered significant at $\mathrm{p}<0.05$.

Treatment of patients with TF was carried out according to the clinical protocols of diagnosis and treatment (CPDT) for surgical treatment of TF, sepsis, disseminated intravascular coagulation syndrome, postoperative nursing of patients, approved by the Scientific Council of the NSMC [19,20,21,22].

\section{Results}

In both groups of patients with complicated course of the postoperative stage, statistical reliability on the basis of age was not found (Table 1, Diagram 1). As can be seen from the Table 1 , radical correction of TF was carried out in 2 stages, the vast majority of patients $(72.6 \%)$ underwent stage 1 - the imposition of SPA mainly at an early age, of which up to 6 months - in $32.8 \%$ of patients, under 3 years - in $55.7 \%$ of patients and over 3 years - in $11.5 \%$ of children. The second stage of RC TF was carried out in children older than 6 months, mainly up to 3 years

Table 1 Ultrasound characteristics of the pelvic organs of patients with abnormal uterine bleeding of puberty

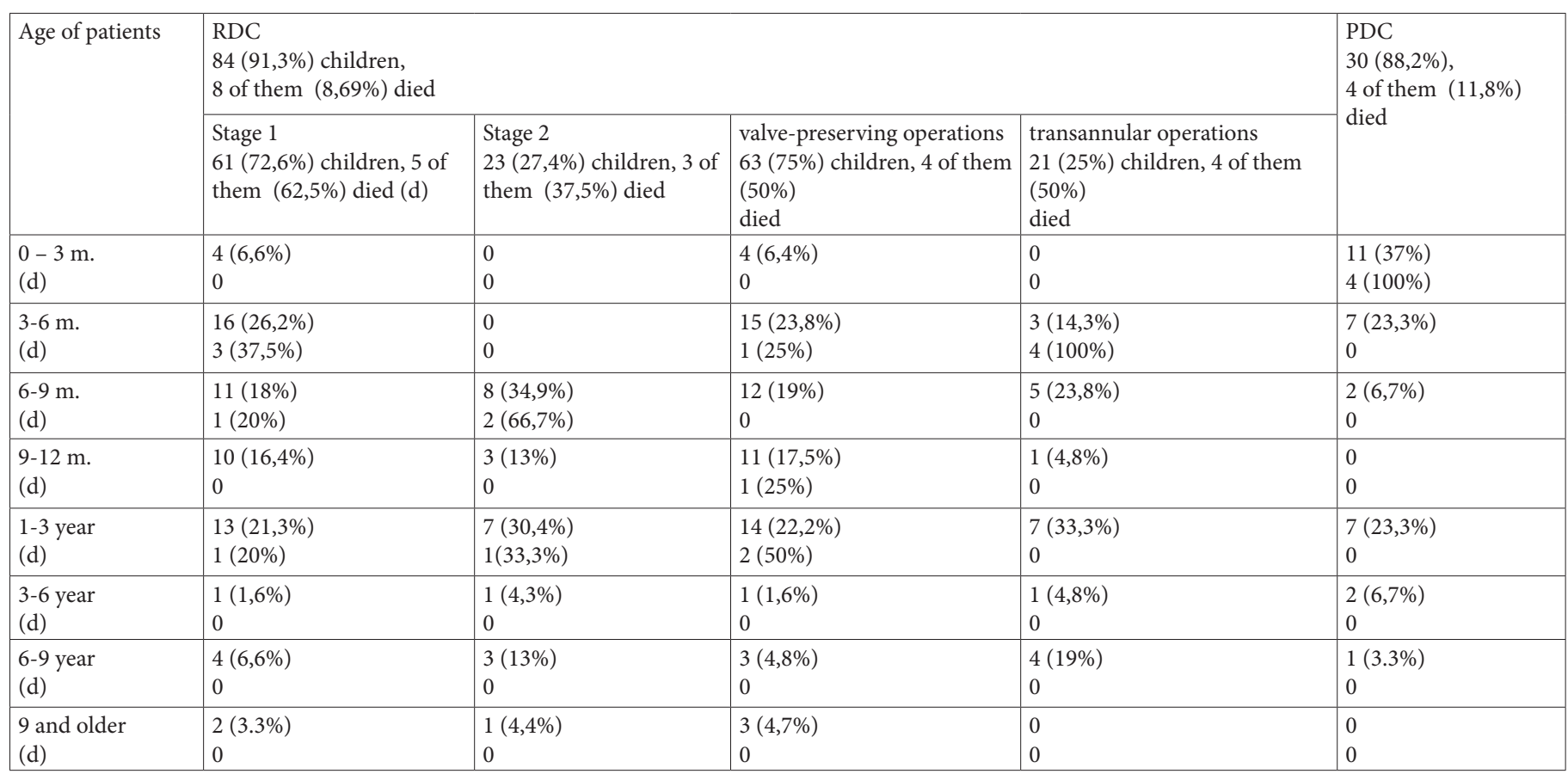


Distribution of operated patients with TF

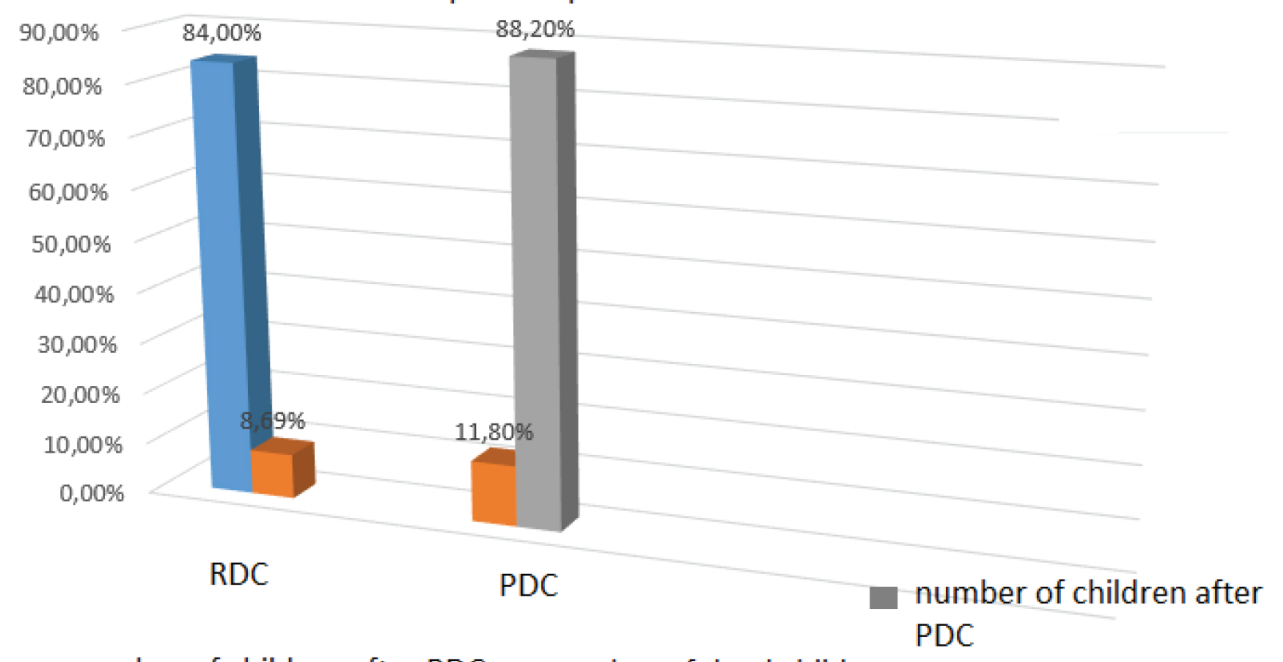

number of children after RDC number of dead children

- in $78.3 \%$ of patients and only $21.7 \%$ of children-over the age of 3 years. In the second group of children with TF, who underwent PCD, the timing of the operation was also determined by life indications. PCD was carried out mainly at the age of 6 months - in $60.3 \%$ of children, up to 3 years - 30\% of children, up to 9 years - in $10 \%$ of children (Diagram 2, 4).

Table 1 shows that the patients were divided according to the surgical correction method (valve-preserving-VP and transannular-TA operations) (Diagram 3). In the vast majority of patients $(75 \%)$ in the RCD was used valve-preserving approach according to clinical protocols, in some patients (25\%) was used transannular approach in children older than 6 months mostly up to 3 years.

The frequency of complications at the hospital stage after

\section{Diagram 2 Operated children 1 and 2 stages}

radical correction of TF was $45.2 \%$ and was due to circulatory insufficiency - $14.6 \%$; rhythm and conduction disorders $-6.6 \%$; purulent-septic complications: pneumonia - 8.4\%, suppuration of the operating wound $-1.2 \%$ and sepsis $-4.8 \%$; disseminated intravascular coagulation syndrome (DIC-syndrome) $-4.8 \%$; multiple organ failure syndrome (MOFS) - 3.6\%; acute violation of cerebral circulation (AVCC) - 1.2\% (Table 2, Diagram 5).

The frequency of complications at the hospital stage after palliative correction of $\mathrm{TF}$ was $50 \%$ and was due to circulatory insufficiency - $13.3 \%$; purulent-septic complications: pneumonia-10\%, sepsis- $6.7 \%$; syndrome of multiple organ failure (MOFS) - 16.6\%; thrombosis of SPA - 3.4\% (Table 2, Diagram 6).

Oxygen saturation in the group after PCD was significantly lower than in the group after RCD (stage 1). The level of hemoglobin was significantly higher in patients in the group after RCD (stage 1) with the heart failure (HF FC IIIIV), compared with patients in the group after PCD $(p<0.05)$. 


\begin{tabular}{|l|l|l|}
\hline Postoperative complications & RDC $45,2 \%$ & PDC 50\% \\
\hline Heart Failure & $14,6 \%$ & $1,3 \%$ \\
\hline Heart rhythm disturbance & $6,6 \%$ & - \\
\hline Pneumonia & $8,4 \%$ & $10 \%$ \\
\hline Suppuration of the operating wound & $1,2 \%$ & - \\
\hline Sepsis & $4,8 \%$ & $6,7 \%$ \\
\hline Disseminated intravascular coagulation & $4,8 \%$ & - \\
\hline Multiple organ failure syndrome & $3,6 \%$ & $16,6 \%$ \\
\hline Acute violation of cerebral circulation & $1,2 \%$ & - \\
\hline Thrombosis of the shunt & - & $3,4 \%$ \\
\hline
\end{tabular}

Diagram 3 Children after valve-preserving and transannular operations

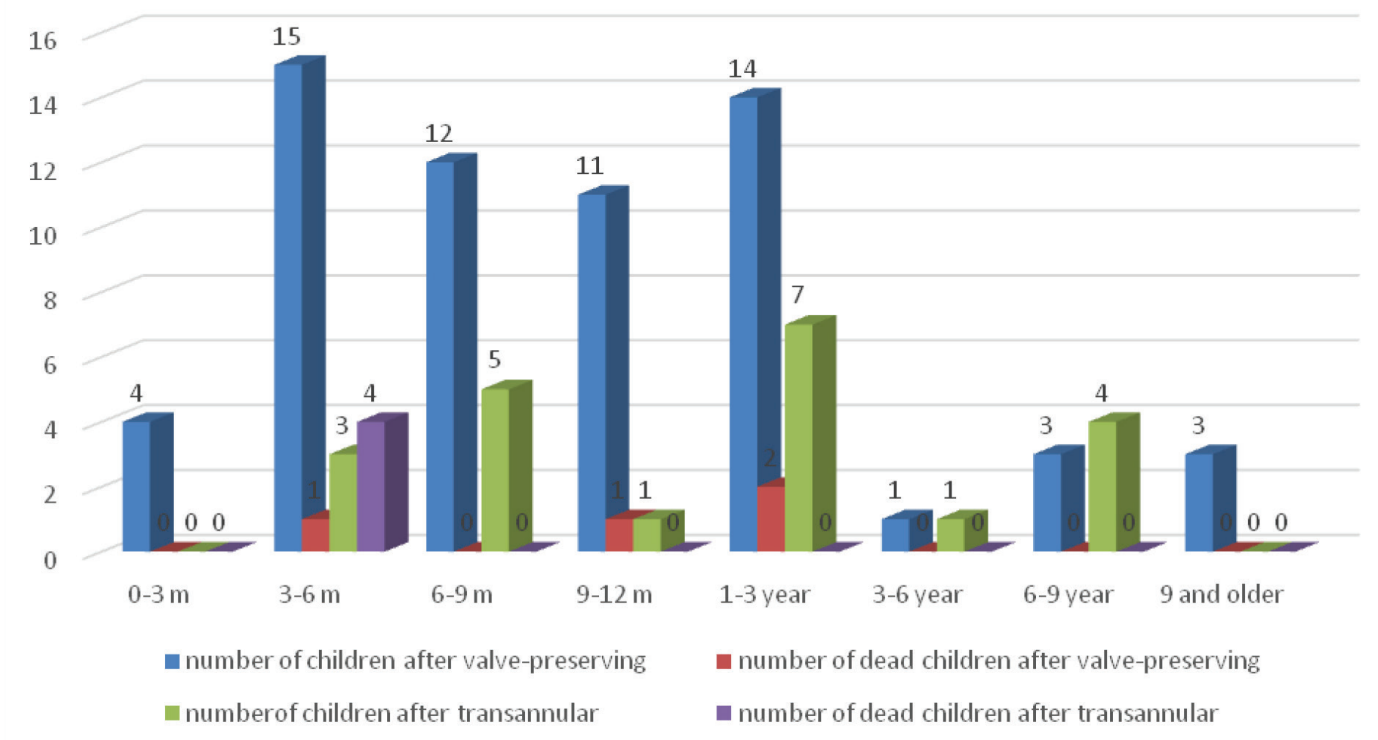

Diagram 4 Children after PDC

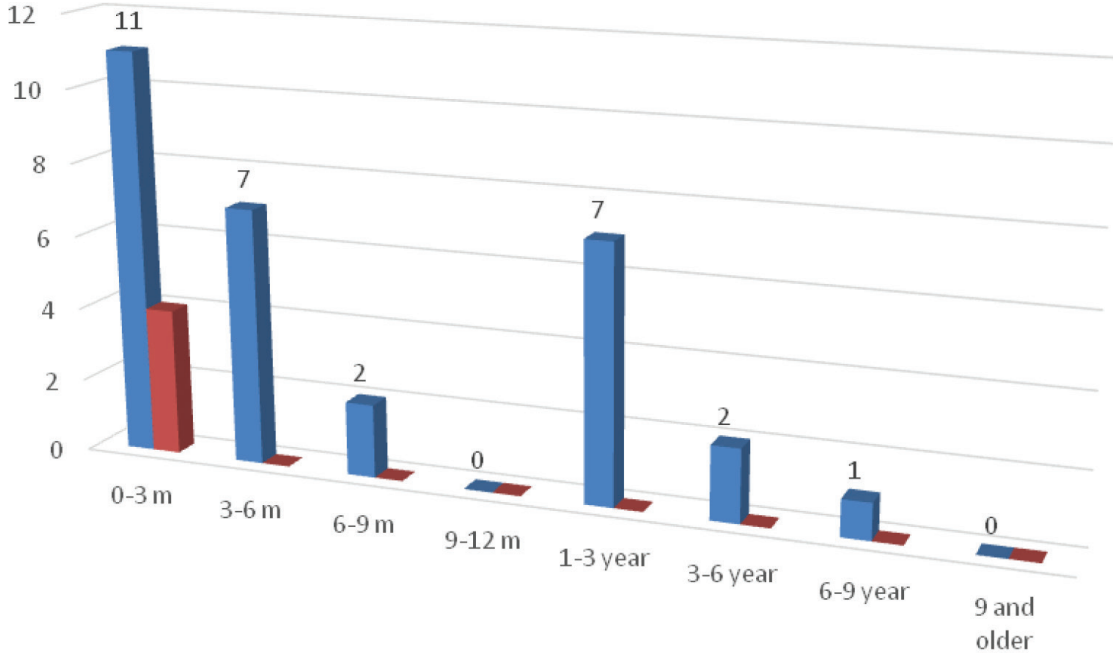

number of children after $\mathrm{PCOD} \quad$ Number of dead children after $\mathrm{PCOD}$ 


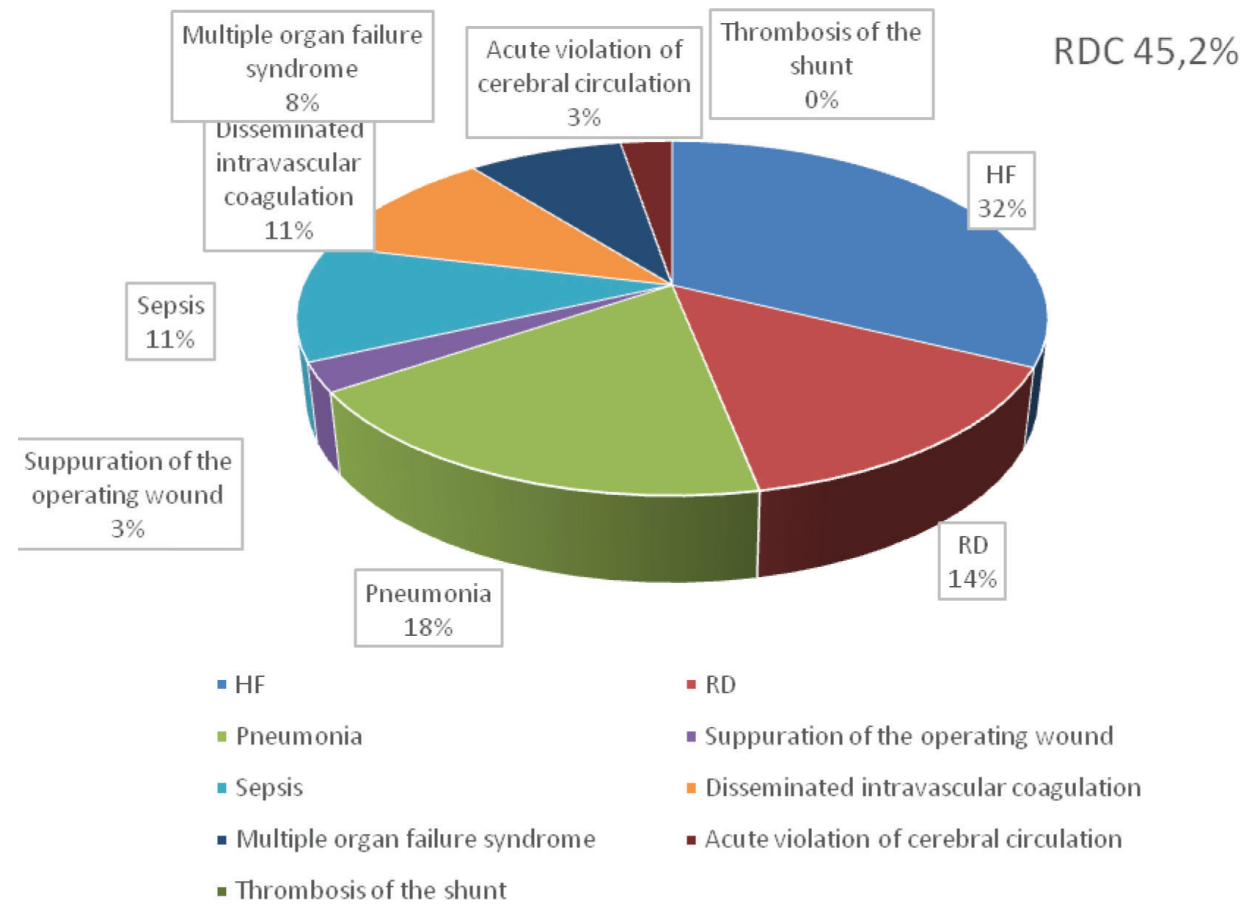

Diagram 6 Postoperative complications after palliative correction of TF

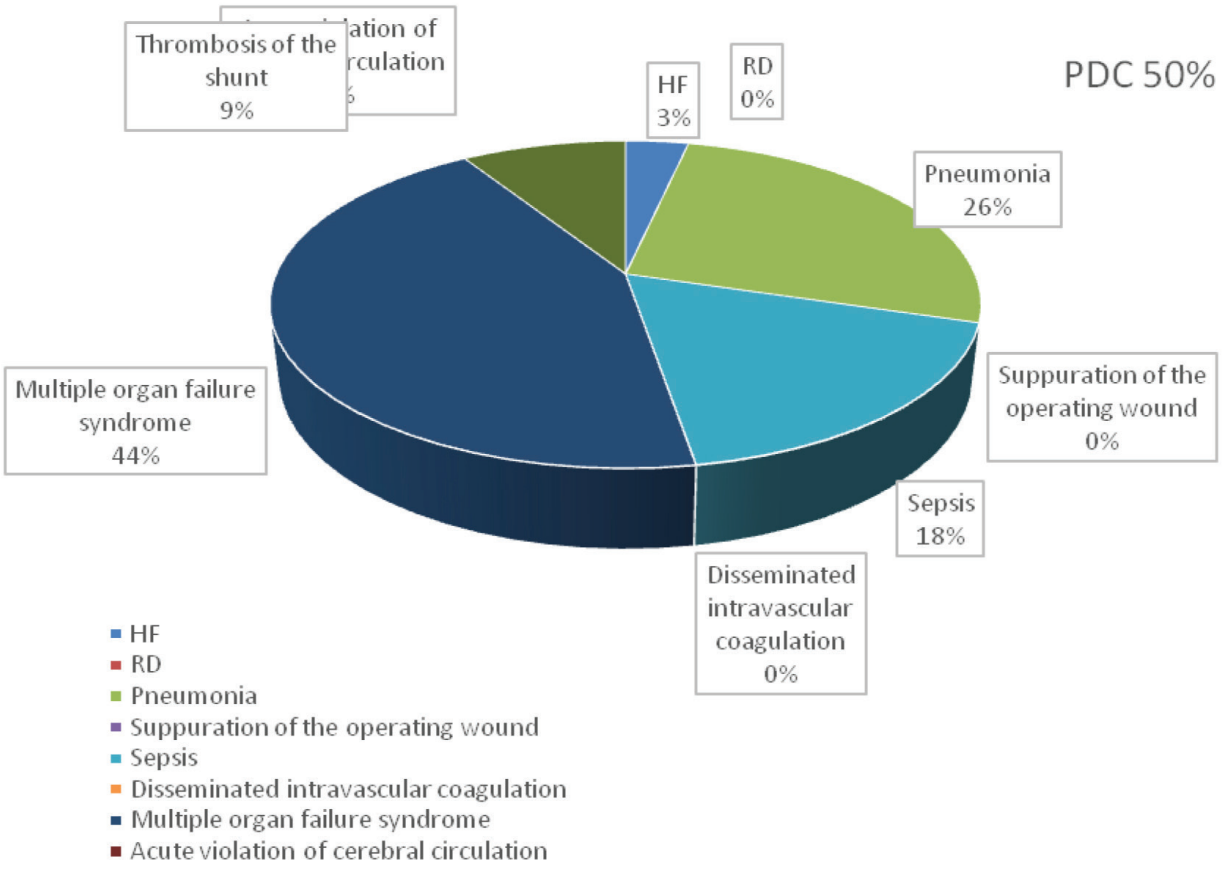

Oxygen saturation less than $80 \%$ was observed in $32(34.8 \%)$ patients of group 1 with complicated course of the postoperative period before surgery, in 60 patients-more than $80 \%$. In group 2, oxygen saturation of less than $80 \%$ was observed in $14(41.2 \%)$ patients.

Extracorporeal circulation (EC) lasted significantly longer in group 1 patients compared to group $2(p<0.05)$. In our studies, it was confirmed the generally accepted opinion that EC more than 120 minutes is a reliable risk factor for the development of HF FC III-IV at the hospital stage [11].
The duration of the resuscitation period was significantly higher in patients with complicated course of the postoperative period (from 3 to 38 days, on average $5.2 \pm 0.76$ days), compared with patients without complications (from 1 to 2.8 days, on average $1.9 \pm 0.16$ days).

In all patients with HF FC III-IV cardiotonic support with dopamine $(7.18 \pm 0.69 \mathrm{mcg} / \mathrm{kg} / \mathrm{min})$ was carried out for more than 2 days, adrenaline $(0.072 \pm 0.01 \mathrm{mcg} / \mathrm{kg} / \mathrm{min})$, in $50 \%$ of patients of group 1 was carried out combined cardiotonic support (dopamine + adrenaline / dobutamine + norepinephrine / simdax). 
In all patients without complications, cardiotonic support lasted less than 2 days (average maximum dose of dopamine $7.22 \pm 0.5$ $\mathrm{mcg} / \mathrm{kg} / \mathrm{min}$; epinephrine $0.05 \pm 0.016 \mathrm{mcg} / \mathrm{kg} / \mathrm{min}$ ).

The ratio of pressure in the right ventricle (RV) and pulmonary artery after radical correction of TF when measured on the operating table was significantly higher in patients with HF FC III-IV (average 0.55 \pm 0.03 ) and purulent-septic complications (average 0.56 \pm 0.03$),(\mathrm{p}<0.001)$, compared with the group of children without complications (average $0.43 \pm 0.02$ ).

Hemodynamically significant risk factors, such as residual ventricular septal defect (VSD) (more than $5 \mathrm{~mm}$ ) - in 35\% of cases, the insufficiency of tricuspid valve (TV) and pulmonary valve (PV) with regurgitation of more than 1 degree - in $72 \%$ of cases, an increase in residual PG on the RV / PA more than 30 mm.hg.art. - were observed $53.4 \%$ of cases after RCD.

In patients with heart failure (HF FC III-IV) in both groups required prolonged artificial ventilation (PAV) (more than 2 days), which averaged $2.9 \pm 0.47,(\mathrm{p}<0.05)$. The risk factor for the development of purulent-septic complications $(p<0.05)$ in the early postoperative period was PAV (more than 2 days) on the background of severe heart failure, concomitant pneumonia and/or secondary immunodeficiency.

In the analysis of ECG data in the group of children after RCD were observed of postoperative complications in the form of violations of rhythm and conduction: complete atrioventricular block (AV-block), which required pacemaker implantation (PM) - $0.6 \%$ of cases; transient AV block, which was stopped after the appointment of anti-inflammatory drugs $-3.4 \%$ of cases and used temporary PM. Supraventricular tachycardia was observed in $3.8 \%$ of cases, which required correction with antiarrhythmic drugs (cordarone).

Pneumonia was confirmed radiologically. Signs of acute septic process were indicated by inflammatory markers (C-reactive protein, presepsin, procalcitonin). In the analysis of microbiological data, pathogens of pneumonia and sepsis were identified: Pseudomonas aeruginosa (24.4\%), Klebsiella (12.2\%), acetonobacter (10.8\%), Staphylococcus aureus (31.5\%), Streptococcus (41.1\%), Enterococcus (10.5\%). In the group of children without postoperative complications, artificial ventilation was carried out for less than 2 days, there were no data for immunodeficiency in blood tests.

\section{Discussion}

The initial severity of the condition of patients with TF was due to heart failure, the degree of hypoxemia, the presence of comorbidity. Tactics of management of patients was determined by vital indications depending on age, severity of the patient's condition, the degree of stenosis of the pulmonary artery (pressure gradient on the RV $\backslash \mathrm{PA}$ ), the presence of risk factors. When analyzing the age categories, it was noted that the PCD was carried out mainly for children up to 3 months on vital signs. At the age of 3 to 6 months, patients were operated on at the first stage of RCD. About $35 \%$ of patients with stage 2 RCD operated at the age of 6 to 9 months, $30 \%$ of children - up to 3 years.

The frequency of complications at the hospital stage after RCD TF was $45.2 \%$ and was due to circulatory insufficiency $14.6 \%$; rhythm and conduction disorders $-6.6 \%$; purulent-septic complications: pneumonia $-8.4 \%$, suppuration of the operating wound $-1.2 \%$ and sepsis $-4.8 \%$; disseminated intravascular coagulation syndrome (DIVC-syndrome) $-4.8 \%$; multiple organ failure syndrome (MOFS) $-3.6 \%$; acute violation of cerebral circulatory failure (AVCC) $-1.2 \%$.

The frequency of complications at the hospital stage after
PCD TF was $50 \%$ and was due to circulatory failure - $13.3 \%$; purulent-septic complications: pneumonia - 10\%, sepsis $-6.7 \%$; MOFS- $16.6 \%$; thrombosis SPA - 3.4\%.

When comparing the structures of complications in 2 groups, the following trends were observed: significantly more often $(\mathrm{p}<0.05)$ complications were observed in the 2nd group (PCD), however, polymorphism of complications was noted in the 1 st group (RCD). Heart failure was more common in group 1, however, pneumonia was more common in group 2. In addition, the development of sepsis was more often noted in group 2, and MOFS was observed in children after PC significantly more often $(p<0.005)$. It should be noted that violations of rhythm and conduction of the heart were observed only in the 1st group, and thrombosis of the shunt - in the 2nd group.

When comparing postoperative complications in groups depending on the method of surgical correction (VP and TA approaches), it is possible to note an unreliably high frequency of postoperative complications in TA technique. Preservation of the anatomical integrity of the pulmonary artery valve in this method in the prognostic sense is more preferable due to the lower frequency of postoperative complications [16].

Risk factors for postoperative complications include oxygen saturation of less than $80 \%$. The severity of the patients with TF was directly related to the level of hypoxemia. More pronounced clinical picture of the disease was in patients with oxygen saturation less than $80 \%$, which is consistent with the literature data $[1,8,13]$. In addition, the severity of patients after PCD (SPA) was more pronounced, which may be associated with early age (up to 3 months), critical condition (desaturation, residual high $\mathrm{PG}$ on the $\mathrm{RV} / \mathrm{PA}$, the presence of combined pathology, immunodeficiency, etc.).

Hemodynamic disorders due to residual VSD (more than $5 \mathrm{~mm}$ ), insufficiency of TV and PV with regurgitation of more than 1 degree, increase in residual $P G$ on the RV/PA above $30 \mathrm{~mm}$.hg. in our studies can be considered risk factors for complications after RCD. Thrombosis of the shunt is a postoperative complication which can be observed after SPA (PCD) and requires urgent surgical intervention due to the sharp deterioration of the patient's condition.

After RCD were observed postoperative complications in the form of rhythm and conduction disorders: full AV-blockade, which required pacemaker implantation (PM) - in $0.6 \%$ of cases; transient AV-blockade of II degree Mobitz I and II, which was stopped after the appointment of anti-inflammatory drugs - in $3.4 \%$ of cases, when applied a temporary PM; supraventricular tachycardia (in $3.8 \%$ of cases), which required the correction of antiarrhythmic drugs (cordarone).

As is known, the duration of the operation depends on the time of EC and the time of clamping (cross) of the aorta. In our studies, we received reliable data that postoperative complications, in particular MOFS (acute renal failure, AVCC , etc.) and DIVC-syndrome, were observed in cases when the time of EC was more than 120 minutes and the time of crossaorta was more than 40 minutes.

Intraoperative blood loss may also have affected the development of DIVC-syndrome after RCD. In our studies, the risk of developing DIVC-syndrome increased with blood loss of more than $10-15 \%$ of the circulating blood volume (CBV).

Prolonged ventilator (more than 2 days) can also be attributed to risk factors for the development of ventilatorassociated pneumonia and sepsis, which was mainly associated with gram-negative infection. During the treatment of patients 
with purulent-septic complications, the bacterial landscape constantly changed, however, the main infectious agent was pseudomonas aerugenosa and/or klebsiella infection, which is expected in this category of patients, since patients are treated in hospitals from birth, receiving intensive therapy using invasive procedures (artificial ventilation, inhalation, bronchopulmonary drainage, vein catheterization and all.)

Passive drainage of cavities using a vacuum system was used in nursing patients in the postoperative period, especially in patients with purulent-septic complications. With long-term, sluggish purulent-septic complications of the postoperative wound, passive drainage with the imposition of a vacuum system showed excellent results.

In the treatment of heart failure, cardiotonics (simdax, adrenaline, norepinephrine, dopamine, dobutamine, milrinon), cardiac glycosides (digoxin), angiotensin converting enzyme inhibitors (enalapril, captopril), beta-blockers (anaprilin, metoprolol), diuretics (furosemide, veroshpiron) were used. Antiarrhythmics drugs (cordarone, lidocaine) were used in the treatment of postoperative complications in the form of rhythm disorders; in cases of transient AV blockade, antiinflammatory drugs (dexamethasone, ibufen) were used, pacemaker implantation was carried out with full AV blockade. At purulent-septic complications complex therapy was carried out. Treatment with antibacterial drugs was carried out taking into account the sensitivity of infectious agents, according to the antibiotic chart. In addition, antibacterial therapy included a combination of 2 or 3 antibiotics, in average therapeutic doses, taking into account the toxicity of the drugs. In the management of patients with sepsis, immunomodulatory therapy of humoral (pentaglobin, octagam, human immunoglobulin) and cellular link (roncoleukin) was also used. Syndromic therapy aimed at correction of MOFS and DIVC syndrome was also performed.

\section{Conclusion}

1. The frequency of complications at the hospital stage after RCD TF was $45.2 \%$ and was mainly due to circulatory failure. In addition, there were complications in the form of rhythm and conduction disorders, purulent-septic complications, DIVC-syndrome, MOFS, AVCC.

2. The frequency of complications at the hospital stage after PCD TF was 50\% and was caused to a lesser extent by the circulatory failure, but to a greater extent by purulent-septic complications, MOFS and thrombosis of SPA.

3. When comparing the structures of complications in 2 groups, it was noted that significantly more often $(\mathrm{p}<0.05)$ complications were observed in the 2 nd group (PCD), however, polymorphism of complications was noted in the 1st group (RCD). Heart failure was more common in group 1, however, pneumonia was more common in group 2. In addition, the development of sepsis was more often noted in group 2, and MOFS was observed in children after PCD significantly more often $(\mathrm{p}<0.005)$. It should be noted that rhythm and conduction disorders of the heart were observed only in the group 1, and thrombosis of the shunt - in the 2nd group.

4. The causes of hemodynamic disorders in patients after RCD TF were risk factors in combination of two and more factors, such as residual VSD (more than $5 \mathrm{~mm}$ ), insufficiency of TV and PV with regurgitation of more than 1 degree, increase in residual $\mathrm{PG}$ on the $\mathrm{RV} / \mathrm{PA}$ more than $30 \mathrm{~mm} \mathrm{hg}$.

5. After RCD there were postoperative complications in the form of rhythm and conduction disorders: full AVblockade, transient AV-blockade of II degree Mobitz I and II, supraventricular tachycardia.

6. Risk factors for the development of purulent-septic complications are: oxygen saturation less than $80 \%$, prolonged extracorporeal circulation (more than 120 minutes) and the time of cross-aorta (more than 45 minutes), prolonged ventilator (more than 2 days) and intra - and postoperative blood loss (more than $10-15 \%$ of CBV).

7. Predictors of purulent-septic complications were: a sharp increase in the level of C-reactive protein, presepsin, procalcitonin and prolonged leukocytosis with neutrophillosis.

8. The use of passive drainage of pleural and/or pericardial cavities, if necessary with the use of a vacuum system, in combination with conservative therapy gives a positive clinical effect of treatment of the circulatory failure after RCD TF (in $92.8 \%$ of cases).

9. Massive antibacterial therapy taking into account the sensitivity of bacterial agents, immunomodulatory, detoxification therapy and active surgical tactics allowed to achieve a positive clinical effect in the treatment of purulent-septic complications.

The article presents for the first time own data of complex analysis of complications that occurred in patients with TF after radical and palliative correction of the defect in the period from 2014 to 2018. The frequency and spectrum of complications are described, risk factors for development of severe stage of circulatory failure and purulent-septic complications are determined and analyzed. The optimal tactics of diagnosis and treatment was determined. The practical application of the results of the work will enable specialists of cardiac surgery clinics, cardiologists of polyclinics to carry out adequate prevention of postoperative complications, diagnosis and treatment of complications at the hospital stage and at the stage of early rehabilitation. Comprehensive assessment of complications in operated patients with $\mathrm{TF}$ at the hospital stage allows to assess the effectiveness of surgical correction.

Thanks to: Marassulov Sh.I., Mishin A.V., Nurkeyev B. A., Kerimkulov A. K., Kanzhigalin D. M., as well as to the entire staff of Pediatric Cardiac Surgery Department, National Scientific Medical Center".

Disclosures: There is no conflict of interest for all authors.

\section{References}

1. Kirklin J.W., Barratt-Boyes B.G. Cardiac surgery: Morphology, diagnostic criteria, natural history, techniques, results, and indications. N.Y.; 2013; 4.

2. Mavroudis C. Pediatric cardiac surgery. Mosby. 2012. https://doi.org/10.1002/9781118320754

3. Omelchenko A.Yu., Soynov I.A., Gorbatykh Yu.N., kulyabin Yu.Y., Gorbatykh A.V., Nichay N.R., Voitov A.V., BogochevProkofiev A.V. Palliative correction in patients with tetralogy of Fallot. Medical Almanac. 2017; 3 (48):28-32

4. Hashemzadeh K., Hashemzadeh S. Early and Late Results of Total Correction of Tetralogy of Fallot. Acta Medica Iranica. 2010; 48(2): 117-122. 
5. Yang S, Wen L, Tao S, Gu J, Han J, Yao J, Wang J. Impact of timing on in-patient outcomes of complete repair of tetralogy of Fallot in infancy: an analysis of the United States National Inpatient 2005-2011 database. BMC Cardiovasc Disord. 2019; 26;19(1):46. https://doi.org/10.1186/s12872-019-0999-1

6. Menaissy Y, Omar I, Mofreh B, Alassal M. Total Correction of Tetralogy of Fallot in the First 60 Days of Life in Symptomatic Infants: Is It The Gold Standard? Thorac Cardiovasc Surg. 2019. https://doi.org/10.1055/s-0039-1678698

7. Martins IF, Doles IC, Bravo-Valenzuela NJM, Santos AORD, Varella MSP. When is the Best Time for Corrective Surgery in Patients with Tetralogy of Fallot between 0 and 12 Months of Age? Braz J Cardiovasc Surg. 2018; 33(5):505-510. https://doi. org/10.21470/1678-9741-2018-0019

8. Zlochevskaya E.V. Diagnosis and treatment of complications arising after radical correction of tetrad of Fallot at the hospital stage. Thesis and abstract on the HAC of the Russian Federation 14.00.06, candidate of medical Sciences. Moscow. 2004.

9. Podzolkov V.P., Alekyan B.G., Kokshenev I.V., Cheban V.N. Repeated operations after correction of congenital heart defects. M.: Bakulev Russian Academy of medical Sciences; 2013.

10. Gatzoulis M.A., Balaji S., Webber S.A. et al. Risk factors for arrhythmia and sudden cardiac death late after repair of tetralogy of Fallot: a multicentre study. Lancet. 2000; 356:975-81 https://doi.org/10.1016/S0140-6736(00)02714-8

11. Küçük M, Özdemir R, Karaçelik M, Doksöz Ö, Karadeniz C, Yozgat Y, Meşe T, Sarıosmanoğlu N. Risk factors for thrombosis, overshunting and death in infants after modified blalock-taussig shunt. Acta Cardiol Sin. 2016; 32(3):337-342. https://doi. org/10.6515/acs20150731a

12. 1Van Straten A., Vliegen H.W., Hazekamp M.G., de Roos A. Right ventricular function late after total repair of tetralogy of Fallot. Eur. Radiol. 2005; 15:702-7. https://doi.org/10.1007/s00330-004-2574-z

13. de Castilhos GM, Ley ALG, Daudt NS, Horowitz ESK, Leiria TLL. Routine Detection of Atrial Fibrillation/Flutter Predicts a Worse Outcome in a Cohort of Tetralogy of Fallot Patients During 23 Years of Follow-Up. Pediatr Cardiol. 2019; 40(5):10091016. https://doi.org/10.1007/s00246-019-02106-2

14. Bacha EA, Scheule AM, Zurakowski D et al. Long-term results after early primary repair of tetralogy of Fallot. J. Thorac Cardiovasc Surg. 2001; 122:154-161 https://doi.org/10.1067/mtc.2001.115156

15. Protocol of diagnosis and treatment republican center for health development of the Ministry of health of the Republic of Kazakhstan from 2015 :"Tetralogy of Fallot in children»

16. Dawoud MA, Abd Al Jawad MN, Hikal T, Samir K. Single-Stage Complete Repair versus Multistage Repair of Tetralogy of Fallot with Borderline Pulmonary Arteries. Heart Surg Forum. 2018; 13;21(6):E466-E471. https://doi.org/10.1532/hsf.2075

17. Tamesberger MI, Lechner E, Mair R et al. Early primary repair of tetralogy of Fallot in neonates and infants less than four months of age. Ann Thorac Surg. 2008; 86:1928-1936. https://doi.org/10.1016/j.athoracsur.2008.07.019

18. Coren ME, Green C, Yates R, Bush A. Complications of modified Blalock-Taussig shunts mimicking pulmonary disease. Arch Dis Child. 1998; 79(4):361-2. https://doi.org/10.1136/adc.79.4.361

19. The Clinical Protocol of treatment and diagnostics "Diagnosis of treatment of DIC syndrome" was approved by the scientific council of NSMC at 09.09.2015.

20. The Clinical Protocol of treatment and diagnosis "Criteria for determining nosocomial infections" was approved by the scientific council of NSMC at 31.01.2012

21. The Clinical Protocol of treatment and diagnostics "Radical correction of Tetralogy Fallot" is approved by the scientific council of NSMC at 31.01.2012

22. The Clinical Protocol of treatment and diagnosis "Cardiac sepsis in children" approved by the scientific council of NSMC at 09.09.2015

How to cite this article: Rakhima Mekenbayeva, Anar Sarsembayeva, Akkerbez Adilbek, Dias Vakpayev, Nigina Mekenbaeva, Arman Akseitov. Complex assessment of complications in operated patients with Fallot's tetrad at the hospital stage. J Clin Med Kaz. 2019; 4(54):25-33 